Katarzyna Kułagowska Silva (Uniwersytet im. Adama Mickiewicza w Poznaniu) kukasia@gmail.com

\title{
Żeniu! Dziecino droga! Historia znajomości łączniczki AK i jej dowódcy Franciszka Studzińskiego
}

Eugenia Starościn, przez bliskich nazywana Żenią, urodziła się 20 stycznia 1918 r. w Zdołbunowie, w guberni wołyńskiej. O jej ojcu wiadomo niewiele. Tylko tyle, że miał pochodzenie rosyjskie, chłopskie, i był pracownikiem kolei w Zdołbunowie. Zmarł na tyfus w 1919 r., pozostawiając żonę i roczną córkę. Eugenię wychowywała samotnie matka Maria z domu Mazacz, która po śmierci męża wróciła $\mathrm{z}$ dzieckiem do rodzinnego Tarnopola. Siostra matki - Natalia Mazacz - kierowała w latach międzywojennych tarnopolskimi Szkołami Powszechnymi Żeńskimi: im. Elizy Orzeszkowej oraz im. Klementyny Hoffmanowej. Była przełożoną Bursy Związku Nauczycielstwa Polskiego przy ul. Sokoła 18. Miała w niej mieszkanie, do którego sprowadziły się Maria wraz z córką. Budynek był pensjonatem dla uczennic gimnazjów. Mieściła się w nim siedziba redakcji „Echa Nauczycielskiego”. Większość mieszkanek należała do drużyn harcerskich. Również Żenia, która uczestniczyła nawet w słynnym Jubileuszowym Zjeździe Harcerstwa Polskiego w Spale w $1935 \mathrm{r}$.

Eugenia ukończyła Państwowe Gimnazjum Żeńskie im. Marszałka Józefa Piłsudskiego w Tarnopolu. W 1937 r. wstąpiła na Uniwersytet Jana Kazimierza we Lwowie, gdzie studiowała na wydziale matematyki. Do wybuchu II wojny światowej złożyła cztery egzaminy magisterskie: $\mathrm{z}$ filozofii, logiki, algebry i geometrii analitycznej ${ }^{1}$.

${ }^{1}$ Archiwum IV Liceum Ogólnokształcącym im. B. Chrobrego w Bytomiu. Teczka osobowa Eugenii Starościn. Arkusz rejestracyjny do Kuratorium Okręgu Szkolnego Śląskiego w Katowicach z 28 sierpnia $1948 \mathrm{r}$. 


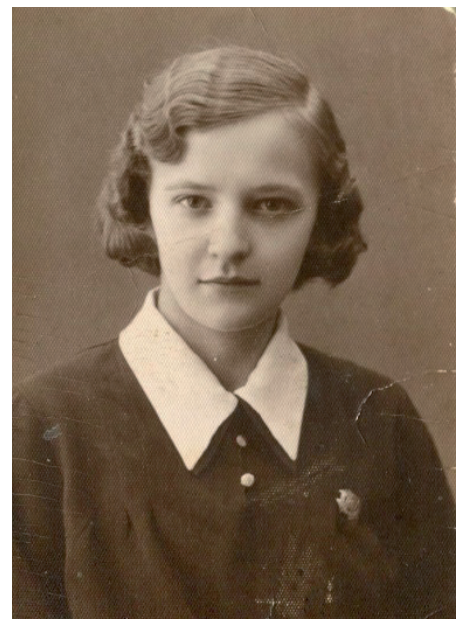

Fotografia legitymacyjna Eugenii Starościn, ok. 1936 r. Zakład fotograficzny L. Muelera. Tarnopol, ul. Mickiewicza 45.

Po napadzie Armii Czerwonej na Polskę we wrześniu 1939 r. obszar tarnopolski znalazł się pod okupacją radziecką. W $1941 \mathrm{r}$. zaczęto organizować struktury Związku Walki Zbrojnej na tym terenie. $W$ tym celu do Lwowa wysłano tzw. grupę warszawską pod dowództwem gen. Kazimierza Sawickiego. Obszarowi lwowskiemu podległy był okręg Tarnopol. Pierwszym komendantem Inspektoratu Rejonowego ZWZ Tarnopol został kpt. Mieczysław Widajewicz. Po nim dowództwo objął ppłk Franciszek Studziński. Jego zastępcą mianowano por. Bronisława Żeglina ps. Ordon.

Armia Krajowa ${ }^{2}$ realizowała operacje „Burza”. Podejmowała działania dywersyjne wymierzone przeciwko wycofującej się pod naciskiem rosyjskich oddziałów armii niemieckiej. Ponieważ rejon tarnopolski przecinała ważna pod względem strategicznym linia kolejowa relacji Lwów-Tarnopol-Kijów, skupiano się na udaremnianiu transportu szynowego - wysadzano mosty, uszkadzano wagony, tory i słupy telegraficzne. W 1943 r., w związku z bestialskimi atakami nacjonalistów ukraińskich z organizacji OUN i UPA na polskie domostwa, Armia Krajowa zajmowała się także ochroną ludności polskiej przed rzezią.

Pułkownik ${ }^{3}$ piechoty Franciszek Studziński ps. Skiba, Skawa, Rawicz, Kotlina, Radwan (ur. 1893 r. w Kotlicach) był doświadczonym żołnierzem. Uczestniczył w wojnie polsko-bolszewickiej. Brał udział $\mathrm{w}$ wyprawie kijowskiej. Za służbę w wojsku polskim został odznaczony Złotym Krzyżem Zasługi, Krzyżem Niepodległości, Krzyżem Virtuti Militari V klasy oraz czterokrotnie Krzyżem Walecznych. W 1939 r. przedostał się na Węgry, gdzie pracował w placówce przerzutu oficerów przy konsulacie polskim. Został aresztowany i osadzony w obozie karnym na Węgrzech, skąd zbiegł w sierpniu 1941 r. na rozkaz gen. Stefana Roweckiego. Po nawiązaniu kontaktów z Komendą Główną ZWZ otrzymał przydział do obszaru lwowskiego. W 1942 r. zamieszkał ze sztabem w bursie Związku Nauczycielstwa Polskiego w Tarnopolu. Z biegiem czasu utworzono w niej punkt kontakto-

214 lutego 1942 r. nazwa ZWZ została przemianowana na rozkaz gen. Władysława Sikorskiego na Armię Krajową.

${ }^{3}$ Franciszek Studziński został awansowany do stopnia pułkownika ze starszeństwem 11 listopada $1943 \mathrm{r}$. 


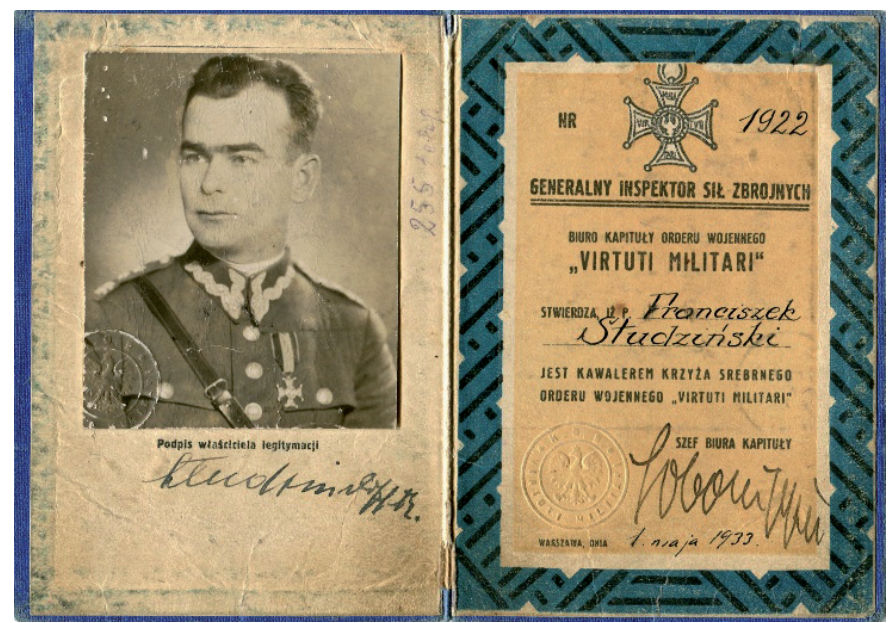

Legitymacja kawalera Krzyża Srebrnego Orderu Wojennego Virtuti Militari Franciszka Studzińskiego.

Dokument z 1 maja 1933 r. (zbiory prywatne autorki).

wy dla obszaru Lwów oraz podległych dowódcy inspektoratów: Tarnopol, Złoczów, Brzeżany i Czortków. Szefem wywiadu został kpt. Piotr Woźniak ps. Wir; kapelanem - ks. bernardyn Kazimierz Klee ps. Gustaw, proboszcz parafii Kretowce k. Zbaraża.

Eugenia Starościn została zwerbowana do Wojskowej Służby Kobiet we wrześniu 1942 r. przez odpowiedzialną za finanse tej organizacji Helenę Sagańską ps. Bronisława ${ }^{4}$, z którą się przyjaźniła. Obok sióstr Stefanii ps. Basia i Janiny Babireckich ps. Żabka pełniła funkcję łączniczki komendanta Studzińskiego, posługując się kryptonimem Szarotka. Kurierkami Bronisława Żeglina były Krystyna Onychir ps. Wanda (kuzynka Eugenii Starościn) oraz Kamila Zarychta ps. Kama, Adriana. Do ich zadań należało dostarczanie meldunków i przesyłek do inspektoratów oraz kolportowanie podziemnej prasy do ludności polskiej, np. wydawanego na powielaczu tygodnika „Polak Kresowy”. Jeden z punktów kontaktowych mieścił się w mieszkaniu Józefy Onychir, na kolonii urzędniczej przy ul. Baworowskiego $1^{5}$. Kolejny znajdował się w mieszkaniu Basi przy pl. Sobieskiego w Tarnopolu' ${ }^{6}$. Punkt łącz-

\footnotetext{
${ }^{4}$ Instytut Pamięci Narodowej, Oddział w Poznaniu. Protokół przesłuchania podejrzanego. Zielona Góra, 4 maja 1953 r. Zeznania Eugenii Starościn w WUBP. IPN Po 2/2254/1, s. 139.

${ }^{5}$ Tajną pocztę przechowywano w skrytce pod podłogą. Leszek Onychir, Armia Krajowa rodem z Tarnopola. Z dziejów kresowej organizacji AK -WiN, Gdańsk 2010, s. 15. Praca wydrukowana w kilku egzemplarzach $w$ charakterze pamiątki rodzinnej.

${ }^{6}$ Instytut Pamięci Narodowej, Oddział w Poznaniu. Protokół Przesłuchania podejrzanego. Zielona Góra, 13 maja 1953 r. Zeznania E. Starościn w WUBP. IPN Po 2/2254/1, s. 147-148.
} 
ności między komórką wywiadu a komendą okręgu znajdował się przy ul. Brodzkiej, w mieszkaniu Anny Bałaj, sekretarki Piotra Woźniaka ${ }^{7}$.

Łączniczka Eugenia Starościn pełniła również funkcję osobistej sekretarki Franciszka Studzińskiego. Z biegiem czasu ich przyjacielska relacja zamieniła się w uczucie. Studziński opiekował się Eugenią i Marią, chronił i traktował je jak rodzinę. W 1953 r. przesłuchiwana przez Wojewódzki Urząd Bezpieczeństwa Publicznego w Zielonej Górze Eugenia zeznała ${ }^{8}$, „[...] jako łączniczka WSK przy Okręgu Tarnopol a między inspektoratami Tarnopol, Brzeżany i Czortków doręczałam korespondencję otrzymaną od kierowniczki WSK Runiewicz Stanisławy ps. Kaliny w Tarnopolu przekazując ją w inspektoracie Tarnopol Żeglinowi Bronisławowi ps. Ordon w Brzeżanach do punktu kontaktowego [skąd] odbierał komendant tegoż inspektoratu nazwiskiem mi nie znanym ps. Dziryt [kpt. Franciszek Garwol], w Czortkowie odbierała nauczycielka ps. Ina [Halina Siwkowska] dla kom. insp. ps. Pumeks [kpt. Stanisław Zygmunt Czerniecki]. Komendantem okr. tarnopolskiego był ppłk Franciszek Studziński ps. Rawicz, którego poznałam osobiście utrzymując z nim przyjaźń [...]. Z Komendą obszaru AK we Lwowie nie stykałam się, jednak stamtąd przyjeżdżały łączniczki bliżej mi nieznane [...]. Przewoziłam literaturę na okres okupacji oraz listy treści mi niewiadomej. Zarychtę Kamilę znam jako łączniczkę Ordona i kiedy była dla niego poczta a spotkałam ją w Tarnopolu to jej doręczałam, a ta z kolei Ordonowi. Runiewicz Stanisława posiadała kasę na cele łączności, natomiast Studziński z chwilą wyzwolenia oddał pieniądze [Irenie] Mogielnickiej ps. Anina a ta z kolei przekazała temu, od którego otrzymał, tj. od Kom. Obszaru Filipowskiego lub Filipowicza [płk. akuba Władysława Filipkowskiego - komendanta obszaru Lwów AK], który się ujawnił przed władzami radzieckimi [...]”. „,...] Otrzymywałam od Babireckiej miesięczną gażę w sumie około 500 zł. emisyjnych za działalność w AK $[\ldots]^{\prime \prime}$.

W kwietniu 1944 r. wojska sowieckie zajęły całkowicie zrujnowany Tarnopol. Miesiąc wcześniej Studziński zdołał wraz z Eugenią i jej matką przedostać się do Lwowa. Tam przebywając, Starościn nadal pełniła funkcję łączniczki - utrzymywała kontakty z okręgiem tarnopolskim. „[...] W 1944 r. w czasie działań wojennych Niemcy wyrzucali ludność z mieszkań za miasto. Razem ze Studzińskim Franciszkiem wyjechałam z Tarnopola do Lwowa, który mówił mi, że będzie nadal kontynuował działalność konspiracyjną $\mathrm{w}$ podle-

7 Tamże, Protokół Przesłuchania podejrzanego. Zielona Góra, 20 maja1953 r. Zeznania E. Starościn w WUBP. IPN Po 2/2254/1, s. 151-152.

8 Tamże, Protokół przesłuchania podejrzanego. Zielona Góra, 4 maja 1953 r. Zeznania Eugenii Starościn w WUBP. IPN Po 2/2254/1, s. 139. Zachowana oryginalna pisownia. Wyjaśnienia i skróty w nawiasach kwadratowych dodane przez autorkę artykułu.

9 Tamże, Protokół przesłuchania podejrzanego. Zielona Góra, 21 maja 1953 r. Zeznania E. Starościn w WUBP. IPN Po 2/2254/1, s. 154. 
głych mu inspektoratach: Złoczów, Brzeżany i Zborów, będące jeszcze pod okupacją niemiecką. Studziński nawiązał kontakt z wym. Inspektoratami oraz z obszarem we Lwowie. Natomiast Runiewicz St. pozostała się na terenie Tarnopola wraz Ordonem [...]”. Również „[...] pozostał się szef sztabu przy Okręgu AK ps. Soroka nazwiskiem Rogala imienia nie znam [major Bronisław Zawadzki; Wiktor Rogala to pseudonim], Żeglin Bronisław ps. Ordon, Woźniak ps. Wir, Runiewicz Stanisława ps. Kalina, Babirecka Stefania ps. Basia i Zarychta Kamila ps. Adriana ${ }^{10}$. Po wkroczeniu Armii Radzieckiej krótko potem dowiedziałam się od Runiewicz we Lwowie, że Soroka został aresztowany przez władze Radzieckie w Tarnopolu. Wymienieni członkowie org. AK trwali w konspiracji [... $]^{\prime 11}$.

W lipcu 1944 r. Franciszek Studziński pełnił obowiązki zastępcy komendanta obszaru lwowskiego Armii Krajowej- gen. Władysława Filipkowskiego. Po zajęciu Lwowa przez Armię Radziecką był członkiem delegacji komendy Obszaru do Żytomierza, gdzie miały się odbyć rozmowy z gen. Michałem Rolą-Żymierskim. W nocy z 2/3 sierpnia 1944 r. cała delegacja została aresztowana przez NKWD. Studzińskiego osadzono w więzieniu w Kijowie, następnie trzy lata internowano w ciężkich obozach jenieckich w Charkowie, Riazaniu-Diagilewie, Griazowcu i Brześciu. Dopiero 4 listopada 1947 r. przekroczył granicę radziecko-polską i zarejestrował się w Państwowym Urzędzie Repatriacyjnym w Białej Podlaskiej. Po Franciszku Studzińskim funkcję komendanta sprawował mjr Bronisław Zawadzki ps. Soroka, do momentu aresztowania przez NKWD w grudniu 1944 r. Ostatnim dowódcą był Bronisław Żeglin, który funkcję tę pełnił do końca $1945 \mathrm{r}$.

Oprócz służby na rzecz owładniętej wojną ojczyzny Eugenia Starościn kontynuowała w roku akademickim 1944/45 studia matematyczne na Uniwersytecie im. Iwana Franki we Lwowie. W tym czasie złożyła dwa egzaminy - z astronomii i fizyki doświadczalnej. Janina Szewczyk, współpracowniczka Eugenii w Armii Krajowej, składając w 1974 r. do Związku Bojowników o Wolność i Demokrację oświadczenie o jej działalności podczas wojny, napisała: „[...] była bardzo czynną i gorącą patriotką, przez cały czas pracy narażała życie, wysyłana wszędzie tam, gdzie trzeba było odwagi i samozaparcia. Oceniając jej pracę odznaczyła ją Kom[enda] Gł[ówna] AK - Srebrnym Krzyżem Zasługi z Mieczami [...]"12.

${ }^{10}$ Kamila Zarychta-Zielińska (ur. 29 listopada 1924 r., Zawidowice, pow. Gródek Jagielloński). Mieszka we Wrocławiu.

${ }^{11}$ Instytut Pamięci Narodowej, Oddział w Poznaniu. Protokół przesłuchania podejrzanego. Zielona Góra, 13 maja 1953 r. Zeznania E. Starościn w WUBP. IPN Po 2/2254/1, s. 148.

12 Oświadczenie w zbiorach autorki. Odznaczenie nie zachowało się. Nie udało się również odnaleźć dokumentu poświadczającego jego nadanie. Zdaniem głównego archiwisty Studium Polski Podziemnej w Londynie ustanowione przez Prezydenta RP na uchodźstwie w 1942 r. od- 
W wyniku porozumień jałtańskich Polska utraciła na rzecz ZSRR Kresy Wschodnie. Nastąpił czas przymusowych przesiedleń ludności polskiej w granice obecnej Rzeczpospolitej. Ludność ekspatriowano na podstawie kart ewakuacyjnych - spisów osób i wykazów mienia (restrykcyjnie ograniczonego). Pociągi kierowano w trzech kierunkach: południowym (Kraków, Bytom, Gliwice, Opole, Wrocław, Kłodzko), centralnym (w kierunku Szczecina) i północnym (Pomorze lub Mazury) ${ }^{13}$. Komunistycznemu rządowi zależało na rozproszeniu patriotycznej społeczności polskiej, traktowanej jako „wrogi element". Wśród uchodźców znajdowało się wielu członków Armii Krajowej, wciąż wierzących w wywalczenie niepodległości i odzyskanie ziem. W latach 1945-1946 kilkuset żołnierzy, w tym członkowie okręgu Tarnopol, osiedliło się na Dolnym i Górnym Śląsku oraz Krakowie.

W grudniu 1945 r. w ramach repatriacji przybył na Górny Śląsk Bronisław Żeglin, który osiedlił się w podbytomskich Miechowicach. Tym samym transportem przyjechali Wiktor Rzeźnik ps. Giermek, Czarnohora oraz ksiądz Kazimierz Klee. Wszyscy troje współpracowali pod koniec wojny przy kolportażu pisanego na maszynie „Biuletynu Informacyjnego”, sporządzanego na podstawie nasłuchu zachodnich stacji radiowych w Kretowcach k. Zbaraża. W biuletynach nawoływali do sprzeciwu wobec władzy sowieckiej i zaniechania wyprowadzki na tereny zachodnie. Rzeźnik i Klee osiedli w okolicach Żar; Czarnohora - w Mirostowicach Dolnych, gdzie znalazł zatrudnienie w szkole podstawowej. Klee objął parafię w Lipinkach Łużyckich. Z kolei Irena Mogielnicka, była łączniczka AK we Lwowie, osiedliła się w Czernichowie pod Krakowem i została nauczycielką w Technikum Mechanicznym w Bytomiu.

Żeglin niezwłocznie rozpoczął działalność konspiracyjną. Odnawiał kontakty, by zbudować na terenach ówczesnych województw stalinogrodzkiego i wrocławskiego struktury tzw. eksterytorialnego okręgu tarnopolskiej AK, ale już w ramach zrzeszenia Wolność i Niezawisłość (WiN). Sztab mieścił się w Bytomiu. Okręg podporządkowany został tzw. obszarowi lwowskiemu, którego siedziba znajdowała się w Krakowie. W skład okręgu tarnopolskiego wchodził inspektorat wrocławski, w którego zasięgu pozostawały trzy obwody: Kłodzko, Lwówek Śląski i Żary.

Największa ogólnopolska konspiracyjna organizacja niepodległościowa WiN, kontynuująca tradycje AK i zbudowana na jej kadrach, miała na celu zwalczenie narzuconego po wojnie i w pełni kontrolowanego przez ZSRR systemu komunistycznego oraz odzyskanie władzy przez legalny rząd

znaczenia - Krzyże Zasługi z Mieczami - wysyłane były do okupowanej Polski grupowo, do dowódców okręgów AK, ci przyznawali je zasłużonym według własnego uznania.

13 http:// pl.wikipedia.org/wiki/Wysiedlenie_Polak\%C3\%B3w_ze_Lwowa (dostęp 11 października 2014). 
Rzeczypospolitej Polskiej na uchodźstwie. Za pomocą narzędzi politycznych, takich jak: agitacja, infiltracja komunistycznych struktur władzy i wywiad, chciano doprowadzić do demokratycznych wyborów. WiN stanowiło zagrożenie dla stabilności działalności prosowieckich władz w Polsce, stąd represje, jakim poddawano członków tej organizacji.

We wrześniu 1945 r. do Bytomia przybyła wraz z matką Eugenia Starościn. Przydzielono im mieszkanie przy ul. Wieczorka 42a nr $2^{14}$. Z wartościowych przedmiotów zdołały przywieźć jedynie obraz Kossaka, który z powodu późniejszych wydarzeń, skutkujących brakiem środków do życia, zmuszone były sprzedać za bezcen w desie. Maria Starościn podjęła pracę w szkole podstawowej w Bytomiu-Karbiu. Eugenia wyjechała do Krakowa i przez kolejne lata godziła studia z pracą zawodową. W 1947 r. zakontraktowano ją jako nauczycielkę matematyki i fizyki w Państwowej Szkole Zawodowej Żeńskiej w Tarnowskich Górach. W kolejnych latach nauczała tego przedmiotu w Bytomiu: II Gimnazjum i Liceum Męskim, II Szkole Podstawowej i Liceum Towarzystwa Przyjaciół Dzieci (TPD) w Bytomiu, Liceum Ogólnokształcącym nr V w Bytomiu15. W 1952 r. złożyła egzamin magisterski na Wydziale Matematyczno-Fizyczno-Chemicznym Instytutu Matematyki Uniwersytetu Jagiellońskiego. W pracy cieszyła się wzorową reputacją. Wśród opinii zachowanych w obecnym IV Liceum Ogólnokształcącym im. Bolesława Chrobrego w Bytomiu znajdujemy dokument wystawiony przez dyrektora Michała Gonciarza: „Obyw. Starościn Eugenia jest nauczycielką stopnia licealnego [...]. Pracuje w zawodzie nauczycielskim od dnia 1 września 1947 r. jako nauczycielka matematyki. Typ bardzo sumienny i obowiązkowy, każdej pracy podejmuje się i wywiązuje się bez zarzutu. Przez młodzież lubiana. Pracuje wiele w kółku matematycznym i jej wyłączną zasługą jest, że uczniowie zdobywają nagrody w olimpiadzie matematycznej. Bezpartyjna, ale stosunek jej do obecnej rzeczywistości jest zupełnie pozytywny. Metodycznie i ideologicznie dobrze przygotowana. Zasługuje w całej rozciągłości na poparcie"16. Jeden z jej uczniów, Henryk Bogdanów, został w 1953 r. zwycięzcą Olimpiady Matematycznej. Za to nieprzeciętne osiągnięcie pedagogiczne komitet główny Olimpiady przyznał Eugenii nagrodę pieniężną, o czym dowiedziała się... podczas pobytu $\mathrm{w}$ areszcie Wojewódzkiego Urzędu Bezpieczeństwa Publicznego w Zielonej Górze (o czym w dalszej części artykułu).

W styczniu 1946 r. Eugenia Starościn spotkała w Bytomiu Bronisława Żeglina17, który oświadczył jej, iż kontynuuje działalność w konspiracji.

14 Obecnie ulica ta nosi nazwę P. Woźniaka. Numer domu pozostał ten sam.

15 Archiwum IV LO im. Bolesława Chrobrego w Bytomiu. Teczka osobowa E. Starościn. Ankieta personalna z 6 grudnia $1952 \mathrm{r}$.

16 Tamże.

17 Instytut Pamięci Narodowej, Oddział w Poznaniu. Protokół przesłuchania podejrzanego. Zielona Góra, 3 lipca 1953 r. Zeznania E. Starościn w WUBP. IPN Po 2/2254/1, s. 187-188. 
Zaproponował jej współpracę, na co się zgodziła. Jej zadaniem były wyjazdy do Krakowa, gdzie przekazywała tajną pocztę kurierce Kamili Zarychcie (odnowiły ze sobą kontakt w 1945 r., gdyż obie studiowały na Uniwersytecie Jagiellońskim). Zarychta przywoziła przesyłki do punktu kontaktowego w mieszkaniu swojej matki, która po repatriacji zamieszkała w Żarach przy ul. Legnickiej 17. W Bytomiu wyznaczonym lokalem kontaktowym było mieszkanie matki Żeni, w którym Zarychta zostawiała pocztę zwrotną do komendanta Żeglina. Oczywiście, matki wiedziały o wszystkim, gdyż także należały do organizacji. Odbiorcą korespondencji przekazywanych Zarychcie był m.in. podległy Ordonowi komendant obwodu żarskiego Wiktor Rzeźnik, do którego zadań należały: organizacja lokali kontaktowych, opracowywanie raportów, pozyskiwanie ludzi do pracy w podziemiu, przygotowywanie konspiracyjnej literatury. Kolejnymi osobami z grupy Ordona byli: podporucznik Józef Kraśnicki ps. Godlewski, zam. w Lipinkach Łużyckich, oraz dowódca dolnośląskiego inspektoratu porucznik Mieczysław Lipa ps. Wichura.

Wśród dokumentów przekazywanych od Ordona za pośrednictwem Szarotki i Adriany do Czarnohory były m.in.: instrukcje dotyczące organizowania siatki wywiadowczej WiN, zbierania informacji o władzach komunistycznych i ich działaniach zwalczających dążenia niepodległościowe, tj. władzach partyjnych, administracyjnych i wojskowych, terenowych strukturach Urzędów Bezpieczeństwa Publicznego i Milicji Obywatelskiej, konfidentach. W przesyłkach znajdowały się: wykazy repatriantów zamieszkujących okolice Żar, biuletyny informacyjne WiN-u, periodyki „Strażnica Kresowa”, zawierające treści krytyczne wobec komunistycznego ustroju. Były w nich instrukcje dla obywateli polskich co do słusznego sposobu głosowania "na nie" w planowanym 30 czerwca $1946 \mathrm{r}$. referendum ludowym zwanym "trzy razy tak". Agitowano również obywateli, by w wyborach 1947 r. poparli PSL kierowane przez Stanisława Mikołajczyka. Działania okazały się daremne, gdyż oba plebiscyty władze PRL sfałszowały.

Opuszczając Tarnopol, Kamila Zarychta przywiozła do Krakowa na polecenie komendanta Żeglina archiwum Armii Krajoweje ${ }^{18}$, które początkowo ukrywała w krakowskim mieszkaniu przy ul. Starowiślnej 27, a potem $\mathrm{w}$ domu akademickim. Starościn odebrała od niej tę cenną dokumentację $^{19}$, którą najprawdopodobniej przekazała Żeglinowi. Przesłuchiwana przez bezpiekę w Zielonej Górze, wyparła się tego: „[...] Archiwum żadnego od Zarychty w Krakowie w dniu 2 maja 1946 nie odbierałam i nie było mi wiadomo aby Zarychta posiadała jakiekolwiek archiwum organizacyj-

18 Tamże. Protokół przesłuchania podejrzanego. Zielona Góra, 10 lipca 1953 r. Zeznania Kamili Zarychty w WUBP. IPN Po 2/2254/2, s. 203.

${ }^{19}$ Tamże, s. 206-209. 
ne [...]”20. Natomiast Zarychta oświadczyła: „[...] w Krakowie przechowywałam archiwum Ordona i zostało ono zabrane 2 maja 1946 r. przez łączniczkę ps. Ordona Starościn Eugenię i dobrze się złożyło, gdyż w następnym dniu $\mathrm{z}$ racji mego zatrzymania $\mathrm{w}$ związku $\mathrm{z}$ moim udziałem $\mathrm{w}$ manifestacji 3-cio majowej - była u mnie w pokoju przeprowadzona rewizja i byłoby dostało się w ręce władz [... $]^{\prime 21}$.

W zeznaniach Eugenii padają inne jeszcze informacje, które mogły być próbą zmylenia śledczych: „W 1946 r. będąc ponownie w Bytomiu otrzymałam od Runiewicz Stanisławy paczkę, w której przypuszczam było archiwum, z poleceniem podania ob. Lewkowiczowej zam. w Bierzanowie pow. Kraków, która osobiście archiwum odebrała. W końcu 1946 r. żona Żeglina Bronisława prosiła mnie bym jej pomogła przenieść pakunki, z których jeden zawierał materiały organizacyjne i jak mi mówiła wiezie je do swego brata nazwiskiem mi nie znanym zam. w Bielsku lub w Dziedzicach. Zarychcie Kamili poczty nie doręczałam, odnośnie zaś archiwum Ordona twierdzę, albo jest w Bierzanowie albo u brata Ordonowej. Nie przypominam sobie, abym od Zarychty odebrała archiwum [...]"22.

W pierwszych latach po wojnie Służba Bezpieczeństwa PRL intensywnie rozpracowywała środowisko byłej Armii Krajowej i poszukiwała jej członków, przesiedlonych z Kresów. Pod koniec 1946 r., w związku z masowymi aresztowaniami członków WiN, Bronisław Żeglin postanowił zakończyć działalność w organizacji. Opuścił Górny Śląsk i ukrywał się. Nakazał członkom WiN, aby nie ujawniali swojej działalności w zrzeszeniu.

W grudniu 1946 r. Eugenia Starościn przyjechała na ferie świąteczne do matki. W tym czasie gościły tam dzieci Juliana Kułagowskiego i Kamili z domu Mazacz - jej kuzyni: Bogumiła, Teresa i Józef. Mieszkanie od dłuższego czasu było obserwowane, a członkowie rodziny śledzeni przez bezpiekę. 9 stycznia 1947 r. funkcjonariusze Powiatowego Urzędu Bezpieczeństwa Publicznego urządzili w nim „kocioł”. Wtargnęli, dokonując zatrzymania Marii i Eugenii. W mieszkaniu przez dwa tygodnie, wraz z kilkunastoletnimi dziećmi, pozostali uzbrojeni ubecy. „Byłam świadoma, czym zajmuje się ciotka i kuzynka. Sama nieraz otrzymywałam zawiniątka, robótki ręczne, w których znajdowały się przesyłki. Zanosiłam je pod wskazane adresy. W domu często pojawiali się obcy ludzie. Wiedzieliśmy, że mamy zachować ciszę i że to ważne. Kiedy przyszło UB? Najpewniej w nocy, gdyż samego momentu nie kojarzę. Przebywało z nami co najmniej dwóch funkcjonariuszy. Jeden

20 Tamże. Protokół przesłuchania podejrzanego. Zielona Góra, 23 maja 1953 r. Zeznania E. Starościn w WUBP. IPN Po 2/2254/1, s. 155.

21 Tamże. Protokół przesłuchania podejrzanego. Zielona Góra, 10 lipca 1953 r. Zeznania Kamili Zarychty w WUBP. IPN Po 2/2254/2, s. 208.

22 Tamże. Protokół przesłuchania podejrzanego. Zielona Góra, 4 maja 1953 r. IPN Po 2/2254/1, s. 140. 
miał rewolwer. Kazał mi otwierać drzwi wejściowe, gdy ktoś zapukał. Stał za mną trzymając broń przy mojej głowie. Każdego zatrzymywali. Nawet sąsiadkę z naprzeciwka. Pewnego dnia stanął w progu mężczyzna ze skórzaną teczką w ręce. Wcześniej często go widywałam. Wiedziałam, że to ważna osoba. Chciałam go ostrzec. Starałam się szybko zatrzasnąć uchylone drzwi. Nie udało się. Zostałam odepchnięta a mężczyzna wciągnięty do środka. Zemdlał. W jednej chwili runął na podłogę. Rozpłakałam się. Oni na niego musieli czekać, bo złapali go, wyprowadzili i więcej się nie pojawili" - tak te wydarzenia zapamiętała Teresa Kułagowska-Szymańska ${ }^{23}$.

Postępowanie w sprawie aresztowanych prowadził Wojewódzki Urząd Bezpieczeństwa Publicznego w Katowicach. Po dwóch miesiącach Eugenia została z braku dowodów zwolniona. Oficer śledczy WUBP Zygmunt Siuda umorzył śledztwo, wskazując, że „podejrzana do zarzucanych jej przestępstw nie przyznaje się" ${ }^{24}$. Pomimo uchwalenia przepisów o amnestii Eugenia nie ujawniła działalności w WiN, ponieważ obawiała się, że zdradzając swoje zaangażowanie w organizacji, zaszkodzi matce. "Nie ujawniłam się w 1947 r., ponieważ przeciwko mojej matce toczyło się śledztwo, gdzie matka została pobita i miałam obawę, że z powrotem rozpocznie się śledztwo przeciwko mnie, a zwłaszcza matce $[\ldots]^{\prime 25}$, , [...] Nie ujawniłam się dlatego, że byłam aresztowaną i nie wiedziałam, czy amnestia mnie będzie tyczyć. W marcu wyszłam z aresztu na wolność [...]"26. Marii Starościn funkcjonariusze Służby Bezpieczeństwa wybili zęby ${ }^{27}$.

Siedmiu członków organizacji WiN z Bytomia - Edwarda Szlagora, Kazimierza Kulpę, Władysława Gancarczyka, Tadeusza Popławskiego, Tomasza Smolińskiego, Romana Skoczylasa, Franciszka Pankiewicza i Marię Starościn - postawiono w stan oskarżenia. Treść aktu w odniesieniu do matki Żeni brzmiała: „Starościnowa Maria, c. Ludwika i Anny z d. Czech, ur. 19.7.1894 r. w Tarnopolu, zam. Bytom ul. Wieczorka 42, Polka, rzym. kat., nauczycielka, wykształcenie średnie, wdowa, 1 dziecko, bez majątku, bez odznaczeń, rzekomo niekarana. Oskarżona o to, że: W okresie od miesiąca maja 1946 r. do dnia aresztowania t. j. 9 stycznia 1947 r. na terenie Województwa

${ }^{23}$ Rozmowa z Teresą Kułagowską-Szymańską (ur. 16 października 1932 r. w Kuczkach, zm. 1 czerwca 2015 r. w Krakowie) została przeprowadzona 5 grudnia 2014 r. w Krakowie. Nie wiadomo, kim był zatrzymany mężczyzna. Być może był to jeden ze skazanych w sierpniu 1947 r., wraz z Marią Starościn, bytomskich działaczy WiN.

${ }^{24}$ Instytut Pamięci Narodowej, Oddział w Poznaniu. Postanowienie o umorzeniu śledztwa. Katowice, 22 lutego 1947 r. IPN Po 2/2254/1, s. 141.

25 Tamże. Protokół rozprawy główny. WSR Zielona Góra, 17 grudnia 1953 r. IPN Po 2/2254/2, s. 291.

26 Tamże. Protokół przesłuchania podejrzanego. Zielona Góra, 4 maja 1953 r. IPN Po 2/2254/1, s. 140.

${ }^{27}$ Informacja rodzinna. 
Śląsko-Dąbrowskiego, w mieście Bytomiu, działająca w zamiarze usunięcia władz zwierzchnich narodu, Rządu Jedności Narodowej, zagarnięcia ich władzy, zmiany demokratycznego ustroju Państwa Polskiego, brała udział w nielegalnej organizacji pod nazwą »Wolność i Niezawisłość «, w której to pozostawała zwykłym członkiem. Utrzymywała kontakt z członkami tejże organizacji, omawiała sprawy dotyczące kwestii organizacyjnej z innymi członkami, przechowywała i kolportowała gazetki o treści antypaństwowej. Czynem tym dopuściła się przestępstwa, przewidzianego w art. 86 par. 1 i 2 KKWP. Na zasadzie art. 51 Dekretu z dnia 13 czerwca 1946 r. o przestępstwach szczególnie niebezpiecznych w okresie odbudowy Państwa, sprawa niniejsza podlega rozpoznaniu przez Wojskowy Sąd Rejonowy w Katowicach" ${ }^{28}$. Maria Starościn wyparła się przynależności do organizacji WiN. Wyroki ogłoszono 22 sierpnia 1947 r. Areszt tymczasowy w stosunku do wszystkich oskarżonych, poza Marią, utrzymano w mocy. Matka Eugenii otrzymała wyrok pięciu lat pozbawienia wolności. Karę jednak darowano na podstawie amnestii i dzień później zwolniono. Nie był to, niestety, koniec koszmaru.

„W 1947 r. działalność obwodu WiN dowodzonego przez Wiktora Rzeźnika została zawieszona, ponieważ bezpieka zlikwidowała kilka grup organizacji. W wyniku aresztowania przez UBP Wrocław w dniu 18.08.1948 r. komendanta rejonu wrocławskiego Mieczysława Lipy ujawniono działalność obwodu żarskiego WiN, którym dowodził Rzeźnik. W 1948 r. PUBP Żary rozpoczął intensywne rozpracowywanie operacyjne członków obwodu żarskiego WiN, w którym wykorzystano trzech tajnych współpracowników. Rozpracowanie zakończono aresztami W. Rzeźnika, K. Zarychty i E. Starościn. Broń i przechowywane przez Rzeźnika archiwum skonfiskowano" ${ }^{29}$. „W wyniku prowadzonego śledztwa p-ko Rzeźnikowi Wiktorowi i Zarychcie Kamili wyszły na jaw nowe okoliczności, a mianowicie, że Starościn Eugenia ps. Szarotka po wyzwoleniu spod okupacji hitlerowskiej na terenie Bytomia i Krakowa do chwili obecnej była czynnym członkiem kontrrewolucyjnej bandy »WIN «, w której pełniła funkcje łączniczki" ${ }^{30}$.

28 listopada 1952 r. funkcjonariusze WUBP w Zielonej Górze zatrzymali Wiktora Rzeźnika. Ten sam los spotkał Kamilę Zarychtę. Ostatnia w ręce bezpieki dostała się Eugenia. 27 kwietnia 1953 r. WUBP podstępnie, pod pozorem przesłuchania w charakterze świadka, nakazał jej przyjazd do Zielonej Góry.

\footnotetext{
${ }^{28}$ Instytut Pamięci Narodowej, Oddział w Katowicach. Akt oskarżenia z dnia 7 marca 1947 r. IPN Ka 03/1351, s. 143.

${ }^{29}$ Instytut Pamięci Narodowej, Oddział w Poznaniu. Charakterystyka nielegalnej organizacji pn. "Wolność i Niepodległość” obwód ps. „Zefir” działający w latach 1946-1952 na terenie powiatu Żary. Zielona Góra, 18 lipca 1978 r. Oprac. por. Jadwiga Jankowska. IPN Po 060/119/37/1, s. $2-3$.

${ }^{30}$ Tamże. Postanowienie o wznowieniu umorzonego śledztwa z dnia 11 maja 1953 r. WPR Zielona Góra. IPN Po 2/2254/1, s. 143.
} 
Została zrewidowana i zatrzymana. Przeciwko wymienionej trójce wszczęto śledztwo, które prowadził oficer śledczy WUBP w Zielonej Górze ppor. Tadeusz Gąsiorek ${ }^{31}$. Postanowieniem z 11 maja 1953 r. prokurator Wojskowej Prokuratury Rejonowej w Zielonej Górze kpt. Zbigniew Domino uchylił postanowienie WPR w Stalinogrodzie z 1947 r. o „umorzeniu śledztwa p-ko Starościn Eugenii podejrzanej o przynależność do kontrrewolucyjnej bandy $\mathrm{WiN}^{\prime \prime} \mathrm{z}$ art. 86. par. 2. KKWP 32 oraz wznowił tamto postepowanie ${ }^{33}$. Wydał polecenie aresztu z terminem do 2 lipca 1953 r., które następnie sukcesywnie przedłużał, ponieważ „, sprawa wymagała dalszego rozpracowania" ${ }^{\prime 34} .10$ sierpnia 1953 r. zamknięto śledztwo, dwa tygodnie później sporządzono akt oskarżenia. 7 października 1953 r. Wojskowy Sąd Rejonowy w Warszawie w składzie: przewodniczący mjr Juliusz Surażski, referent mjr Piotr Adamowski, wotant kpt. Stanisław Gutaker, protokolant ppor. Sylwester Kenkowski, rozpoznał pozytywnie wniosek Naczelnej Prokuratury Wojskowej w Warszawie z 28 września w sprawie przedłużenia aresztu do 15 listopada $1953 \mathrm{r} .{ }^{35}$ Areszt postanowiono przedłużyć do 4 grudnia 1953 r. i „utrzymać je nadal w mo-

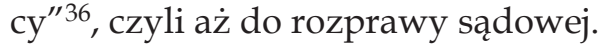

Osadzeni w areszcie WUBP byli przez kilka miesięcy poddawani wielogodzinnym przesłuchaniom. Śledczy konfrontowali ich ze sobą, by zidentyfikować osoby związane z podziemiem, znane im często wyłącznie z pseudonimów $^{37}$. Domagali się informacji o działalności w AK i WiN, pełnionych funkcjach, posiadanych kontaktach, miejscach zamieszkania. Zeznania egzekwowano przemocą psychiczną i fizyczną. Potwierdza to świadectwo Lubomiry Rzeźnik, ujęte w podaniu z 22 maja 1991 r. do ministra sprawiedliwości o wniesienie rewizji nadzwyczajnej od wyroku na korzyść jej zmarłego już wówczas męża Wiktora, że u niego zeznania wymuszano stosowa-

31 Tamże. Postanowienie o wszczęciu śledztwa. Zielona Góra, 2 maja 1953 r. IPN Po 2/2254/1, s. 136.

32 Paragraf ten brzmiał: „Kto usiłuje przemocą zmienić ustrój Państwa Polskiego, podlega karze więzienia na czas nie krótszy od lat 5 albo karze śmierci". Dekret Polskiego Komitetu Wyzwolenia Narodowego z 23 września 1944 r., Kodeks Karny Wojska Polskiego, http:/ /isap. sejm.gov.pl/DetailsServlet?id=WDU19440060027, Internetowy System Aktów Prawnych (dostęp 5 marca 2015).

${ }^{33}$ Instytut Pamięci Narodowej, Oddział w Poznaniu. Postanowienie o wznowieniu umorzonego śledztwa. IPN Po 2/2254/1, s. 143.

34 Tamże. Wniosek. IPN Po 2/2254/1, s. 186.

35 Tamże. Postanowienie. Znak akt 572/53. IPN Po 2/2254/2, s. 243.

36 Tamże. Protokół odczytania aktu oskarżenia. IPN Po 2/2254/2, s. 267.

37 Tamże. IPN Po 2/2254/1. W archiwum IPN znajduje się wiele protokołów przesłuchań Starościn, Rzeźnika, Zarychty oraz innych wzywanych bądź zatrzymanych w sprawie członków podziemia, m.in.: Studzińskiego, Mogielnickiej, M. Starościn, ks. Klee. W maju 1953 r. Tadeusz Gąsiorek przesłuchiwał Eugenię w dniach: 4, 12, 13, 20, 21, 23; w czerwcu: 10; w lipcu: 3, 14 (konfrontacja z Kamilą Zarychtą), 15; w sierpniu: 8. 


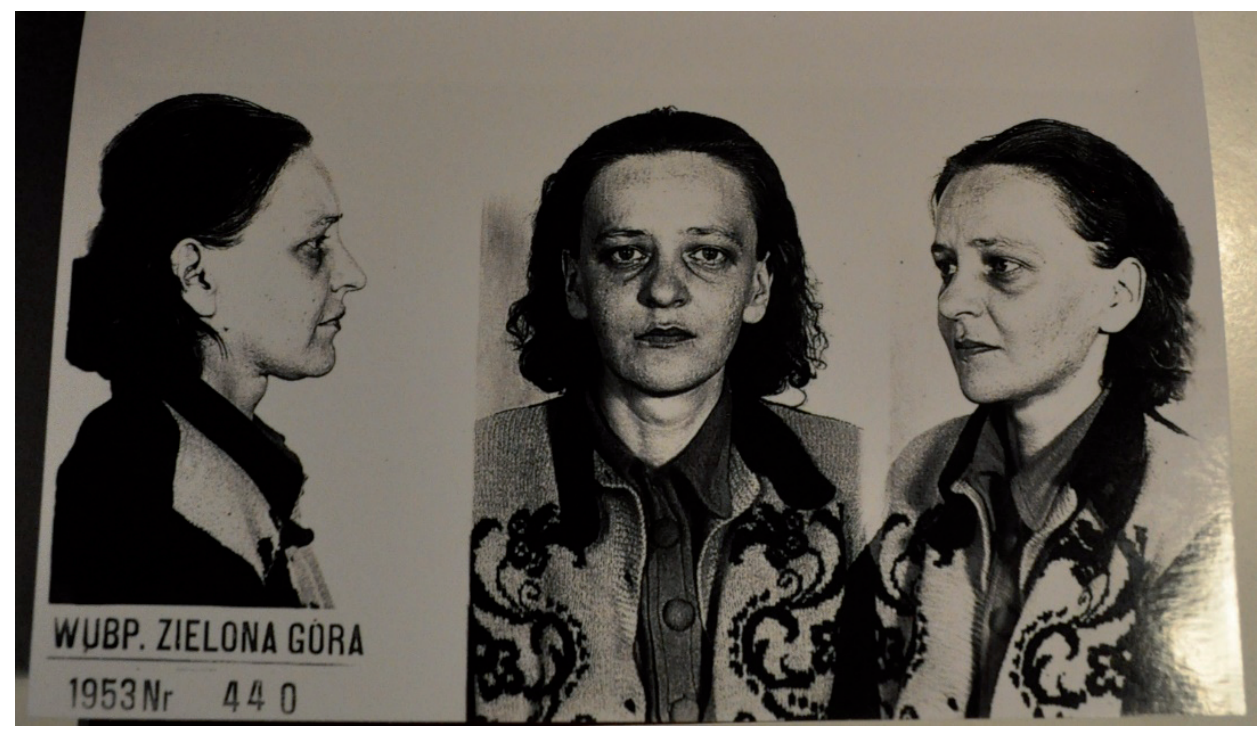

Eugenia Starościn w areszcie WUBP w Zielonej Górze. Miała wówczas 35 lat. Źródło: L. Onychir, dz. cyt., s. $46 \mathrm{a}^{38}$.

niem tortur ${ }^{39}$. Wiele o metodach bezpieki mówi również fotografia 35-letniej Eugenii zrobiona w areszcie WUBP w Zielonej Górze.

3 grudnia 1953 r. prokurator Wojskowej Prokuratury Rejonowej Zbigniew Domino wydał postanowienie o zatwierdzeniu aktu oskarżenia ${ }^{40}$. Eugenii zarzucono $^{41}$, że „W okresie od marca 1944 r. do stycznia 1947 r. w Tarnopolu, Lwowie, Krakowie i Bytomiu była członkiem związku kontrrewolucyjnego AK (Armia Krajowa), a następnie WiN (Wolność i Niezawisłość) mającego na celu przemocą zmienić ustrój Polskiej Rzeczypospolitej Ludowej, w którym pełniła funkcję łączniczki między hersztem tegoż związku Żeglinem Bronisławem »ps. Ordon « a podległymi mu członkami, którym przekazywała rozkazy, instrukcje, raporty, biuletyny antypaństwowe oraz osobiście utrzymywała kontakty z poszczególnymi członkami związku kontrrewolucyjnego, tj. o przestępstwo przewidziane w art. 86 § $2 \mathrm{KKWP}$. Rozprawa odbyła

${ }^{38}$ W udostępnionych mi dokumentach Instytutu Pamięci Narodowej w Poznaniu nie odnalazłam tej fotografii, stąd brakuje sygnatury. Z pewnością jednak zdjęcie pochodzi ze zbiorów IPN.

39 Tamże. Podanie Lubomiry Rzeźnik o wniesienie rewizji nadzwyczajnej z 22 maja $1991 \mathrm{r}$. IPN Po 2/2254/2, s. 253.

40 Instytut Pamięci Narodowej, Oddział w Poznaniu. Akt oskarżenia p-ko Wiktorowi Rzeźnikowi, Kamili Zarychcie i Eugenii Starościn z 25 sierpnia 1953 r., IPN Po 2/2254/2, s. 244.

${ }^{41}$ Tamże, s. 246. 
się 17 i 18 grudnia 1953 r. Bezpieka zadbała o szczególne jej zabezpieczenie ${ }^{42}$. Oskarżonych przewieziono konwojem „pod wzmożoną eskortą MO (4 osoby) samochodem-więźniarką" z aresztu do WSR „w ten sposób, by oskarżeni $w$ drodze nie porozumiewali się". Wyznaczono funkcjonariuszy do obserwacji „elementu WiN-owskiego, którzy bądź w charakterze świadków bądź stron będzie obecny na rozprawie" zarówno w gmachu sądu, jak i od ulicy. Skład sędziowski był następujący: przewodniczący kpt. Stefan Cieślak, ławnicy st. szer. Mieczysław Sroka i szer. Alfred Kwiatkowski, protokolant Wacław Wilczyński, prokurator wojskowy por. Jan Świerkowski. Prokurator domagał się kar dla oskarżonych: piętnaście lat więzienia dla Wiktora Rzeźnika, osiem lat dla Kamili Zarychty i sześć lat dla Eugenii Starościn ${ }^{43}$. W ostatnim słowie Żenia prosiła o łagodny wymiar kary ze względu na matkę, którą miała na utrzymaniu.

21 grudnia 1953 r. Wojskowy Sąd Rejonowy w Zielonej Górze skazał Rzeźnika na łączną karę dwunastu lat więzienia z utratą praw na okres czterech lat i przepadek całego mienia; Kamilę Zarychtę na łączną karę ośmiu lat więzienia (złagodzoną najpierw do lat sześciu, po apelacji adwokata do lat trzech) i utratę praw na okres czterech lat oraz przepadek całego mienia. Eugenię Starościn skazał na karę pięciu lat więzienia oraz utratę praw publicznych i obywatelskich praw honorowych na okres jednego roku oraz przepadek całego mienia, przy czym karę pozbawienia wolności na mocy amnestii darował.

Eugenia Starościn została zwolniona ze stanowiska nauczycielki II Szkoły Towarzystwa Przyjaciół Dzieci w Bytomiu z datą wsteczną, z dniem 31 lipca 1953 r. Pismo o tej decyzji otrzymała dopiero po wyjściu na wolność, w styczniu 1954 r. Otrzymała kolejny cios po traumatycznych wielomiesięcznych przeżyciach w zielonogórskim areszcie. Gwałtownie znalazła się w skrajnie trudnej sytuacji materialnej. Natychmiast podjęła, bezowocne, starania o dalsze zatrudnienie w charakterze nauczyciela. W związku z zapytaniami skierowanymi przez Wydział Oświaty Prezydium Wojewódzkiej Rady Narodowej w Stalinogrodzie o możliwości zatrudnienia Eugenii Starościn w szkolnictwie - szef Wojskowego Sądu Rejonowego w Zielonej Górze udzielił informacji, że „[...] wprawdzie Eugenia Starościn skorzystała z dobrodziejstwa ustawy z dnia 22.02.1947 r. o amnestii, jednak orzeczona utrata praw stoi na przeszkodzie w uzyskaniu stanowiska urzędnika, a więc i nauczyciela do dnia 21 grudnia 1954 r." 44

42 Tamże. Plan zabezpieczenie rozprawy sądowej z 16 grudnia 1953 r. WUBP, Zielona Góra. IPN Po 024/21/ t. 1, s. 177-178.

43 Tamże. Protokół rozprawy główny. IPN Po 2/2254/2, s. 296.

44 Tamże. Pismo Mirosława Mirskiego, Szefa WSR w Zielonej Górze, do Prezydium WRN w Stalinogrodzie. IPN Po 2/2254/2, s. 157. 
Eugenia nie znała losów ukochanego od czasu jego aresztowania przez NKWD w 1944 r. „Studzińskiego Franciszka ps. Rawicz znam jako byłego komendanta Okręgu AK terenu tarnopolskiego, który przyjechał do mnie do Bytomia w 1948 r. tj. po jego przybyciu ze Zw. Radzieckiego. W tym czasie zamieszkiwał w Szczecinie i przyjechał do mnie w celu odwiedzin. Żadnych tematów politycznych nie prowadziliśmy, wyłącznie o sprawach osobistych, miłosnych. Nosiłam się uprzednio w Tarnopolu i ostatnio z zamiarami zamążpójścia za Studzińskiego. Otrzymał on pracę w Niemodlinie w charakterze Pełnomocnika Rządu dla spraw podatku gruntowego. Od tego czasu tj. od 1948 r. Studziński zaczął częściej mnie odwiedzać i mną opiekować się. Był on dla mnie najbliższym człowiekiem. Odwiedzał mnie raz na miesiąc w Bytomiu. Kupował mnie książki i po odbyciu kursu we Wrocławiu Studziński został przeniesiony do Lublińca, gdzie pracował jako Pełnomocnik Rządu do czerwca 1951 r. W tym czasie przeniósł się do PKO w Katowicach na stanowisko mi bliżej nieznane a zamieszkiwał w Częstochowie. W Katowicach pracował do czerwca $1952 \mathrm{r}$. W tym to okresie czasu przebywał u mnie częściej i sypiał u mnie $\mathrm{w}$ mieszkaniu raz na tydzień tj. $\mathrm{z}$ niedzieli na poniedziałek, ponieważ z Bytomia udawał się do Katowic po instrukcje, a tak przez okres tygodnia przebywał $\mathrm{w}$ terenie na kontrolach [...]. W czerwcu $1952 \mathrm{r}$. Studziński Franciszek zamieszkał we Wrocławiu i tam otrzymał pracę, lecz w jakim charakterze i gdzie, tego nie wiem. Będąc we Wrocławiu Studziński jeden raz przyjechał do mnie w listopadzie 1952 r., celem odwiedzin. [...] Rozmawialiśmy między sobą na temat mego egzaminu. Od tego czasu więcej Studzińskiego nie widziałam. W grudniu 1952 r. Studziński Fr. napisał na święta kartę z powinszowaniem i później jak mi wiadomo został aresztowany $[\ldots]^{\prime \prime} 45$.

Studziński trafił w ręce bezpieki 27 grudnia 1952 r. we Wrocławiu ${ }^{46}$. Skazano go w połowie $1953 \mathrm{r}$. na siedem lat więzienia; karę złagodzono do czterech lat i ośmiu miesięcy pozbawienia wolności oraz utratę praz publicznych i obywatelskich praw honorowych na okres trzech lat. Spędził $\mathrm{w}$ więzieniu dwa lata i osiem miesięcy. Resztę kary darowano mu $\mathrm{w}$ drodze łaski ${ }^{47}$. Początkowo przetrzymywano go w więzieniu karno-śledczym w Stalinogrodzie. Następnie w Iławie, gdzie pracował w Przedsiębiorstwie Obróbki Drzewa nr 2. Przez rok prowadził tam również księgowość materiałową. Trzy miesiące odsiedział $\mathrm{w}$ więzieniu w Barczewie, skąd zwolniono go w sierpniu 1955 r. Po wyjściu z więzienia pracował fizycznie w Garbarni

45 Tamże. Zeznania E. Starościn w WUBP w Zielonej Górze z 3 lipca 1953 r. IPN Po 2/2254/1, s. 189.

46 Instytut Pamięci Narodowej, Oddział w Katowicach. Akt oskarżenia przeciwko Studzińskiemu Franciszkowi z 13 maja 1953 r., IPN Ka 032/16/3/1, s. 12-14.

47 Autograf życiorysu Franciszka Studzińskiego z 12 listopada 1955 r. Zbiory prywatne autorki. 
„Poprad” w Łabowej jako pracownik fizyczny i dozorca Hotelu Robotniczego w Bytomiu, jako starszy księgowy w Wojewódzkim Przedsiębiorstwie Transportowym Handlu Wewnętrznego nr 4 w Bytomiu, a także jako starszy inwentaryzator w Przedsiębiorstwie Państwowym „Pieczywo-Nabiał” w Bytomiu ${ }^{48}$.

Zachowało się kilka listów Franciszka do Żeni ${ }^{49}$, które ukazują, jak niesprawiedliwe i mroczne były czasy ich życia.

Żeniu! Dziecino Droga!

14.VI.48

Stale mam przed oczyma Twoją smutną i zmęczoną twarz przy odjeździe pociągu. I oczy Twoje. Te najpiękniejsze i najlepsze oczy pełne łez. Jest we mnie tyle żalu, że to ja jestem winien Twego zmęczenia, Twego smutku.

Żeniu! Jaka to wielka prawda, że oczy to zwierciadła duszy człowieka. W Twoich oczach tak jasno odbiła się piękna i szlachetna dusza Twoja i przeogromna dobroć serca Twego. Twoje piękno, szlachetność i dobroć onieśmiela mnie, kolana się uginają, głowę pochylam w największej pokorze do ziemi, by ucałować ślady Twoich bucików. I wiem że to świętokradztwo z mojej strony, bo nie jestem wart całować ziemi na której stoisz, bo jestem mały i marny człowieczek, wobec Twej wielkiej Świętości. Przebacz mi Żeniu!

Tutaj bardzo źle się czuję moralnie. Jeden, drugi dzień po Twoim wyjeździe próbowałem nadrabiać miną, sztucznym humorem. Później przyszła apatia, a teraz niepokój i po prostu chęć ucieczki. Dzisiaj od rana opanowało mnie jakieś nieznane uczucie lęku, które po prostu sprawia mi ból fizyczny, a w mózgu wiercijak robak pytanie co dalej? Mimo czteroletniego więzienia, mimo okropnych upokarzających warunków bytowania, w których człowiekstaje sięzwierzęciem, pozostało we mnie odrobinę dumy iambicji. Aniczteroletni okres bezprawia iznęcania sięnade mną, ani fakt, żejestem obecnie niczem, że należę „do przeszłości” nie był i nie jest tak straszliwym upokorzeniem, jakie przechodzę obecnie będąc "na łaskawym chlebie”.

Widzisz Żeniu, im bardziej mi źle, tem więcej się śmieję i żartuję. Dlatego nie zdajesz sobie sprawy z mojego tragizmu i okropnej prawdy, którą wypowiadam w żarcie. Ty jesteś dobra, jest w Tobie tylko piękno, szlachetność i oddanie dla drugich. I masz takie wielkie złote promienne serce. Twoja niewinność, widzi tylko dobroć i serdeczność u ludzi. Ja przeciwnie, patrzę inaczej niż ty Żeniu. I nie jest mi tak ciężko przyjąć pomoc od ludzi którym źle się powodzi, jeśli robią to z serca niż od ludzi, którym życie uśmiechnęło się, idzie gładko, opływają we wszystko więc trzeba zaprosić, by móc powiedzieć na prawo i lewo, zaopiekowaliśmy się nim. Dzisiaj, gdybym był zdrowy, poszedłbym do pierwszej lepszej pracy fizycznej, jeśli innej znaleźć nie mogę. Ale zły los ściga mnie dalej i ugodził tak głupią chorobą. Żeniu nie miej mi za złe, że skarżę się, że jestem tak bardzo słabym człowiekiem, głupim i bezradnym. Ale skarżę się na mój zły los tylko przed Tobą. Są ludzie samotni tak jak ja, którzy gdy im źle szukają spokoju i ukojenia w modlitwie. Ja modlę się do ciebie, bo jesteś moim Bogiem. Z najświętszym uczuciem, jakie jest uczucie ojca do swego dziecka, całuję Twoje dobre ręce. Poproś mamusi, by się na mnie nie gniewała i ucałuj Jej rączki. Fr. Następny list przyślę w tym tygodniu i wyjaśnię dlaczego tak późno i niewiele piszę.

\footnotetext{
48 Tamże.

${ }^{49}$ Archiwum rodzinne autorki.
} 
Iława 20. 3. $1955 \mathrm{r}$.

Kochana Żeniu! Twój przyjazd był dla mnie wielką niespodzianką, ale jeszcze większym pozostał zmartwieniem. W zeszłym roku pisałaś mi w liście, że wszystko jest tak jak było dawniej - nic się nie zmieniło, więc byłem zupełnie spokojny o Ciebie. Tymczasem dzisiaj okazało się, że nie wszystko jest jak dawniej. Kochane moje dziecko, bardzo się martwię z tego powodu o Ciebie [...]

Słuchaj dziecko moje - do adwokata się nie zwracaj. Prośbę o warunkowe zwolnienie do sądu wyślę w pierwszych dniach kwietnia, ja sam. A Ty, gdybyś miała możliwości popytaj najwyżej jak sprawa przeszła w sądzie - ale bez adwokata pamiętaj, że szkoda wydawać pieniądze, tem bardziej że ich nie masz. Ja mam wielką nadzieję że zostanę zwolniony a gdyby było inaczej, to nic nie zrobimy - przeznaczeniu trzeba się poddać.

Dziecko moje drogie - pieniędzy mi nie przysyłaj i na nic nie wydaj (naturalnie dla mnie) bo wiesz że ich nie ma, - a ja na nic nie potrzebuję.

Cieszę się Żeniu ogromnie, że Cię widziałem chociaż żal mi Cię bardzo, że całą noc jechałaś, że musiałaś być bardzo zmęczona. Że dużo pieniędzy wydałaś na drogę. Wciąż tylko o tym myślę. I wciąż słyszę Twoje pytanie kilkukrotnie powtórzone, czy Cię poznaję - jakże ja bym Cię nie poznał - Kochana Żeniu! Dbaj o siebie, nie martw się, przecież mnie chyba kiedyś zwolnią bym Cię mógł pilnować i dbać o Ciebie.

Mamusia też bardzo się martwi - prawda. Ale myślę że to się wszystko dobrze skończy dla Ciebie. Nie wiem Żeniu, czy zdążę przed świętami napisać do Ciebie, więc już dzisiaj składam Mamusi i Tobie Życzenia Świąteczne - by nareszcie wszystko co złe i smutne skończyło się i zapanowała dla Ciebie i mamusi radość.

Pytałaś Żeniu gdzie ja piszę - nigdzie nie piszę i nikt nie chce do mnie pisać. Jedynie do Ciebie i parę razy do Markowskich napisałem.

Kończę, nie martw się, pieniędzy nie wysyłaj, bo mi nie są potrzebne.

Ucałuj rączki mamusi i przyjm życzenia jak najlepsze od Franka.

Żeniu!

Barczewo, 1. VIII. 1955 r.

List Twój z dn. 20. VII. otrzymałem. Za troskliwość i pamięć dziękuję. Jestem w Barczewie od 24 czerwca. Żal mi bardzo Iławy, a raczej pracy w Iławie. Tutaj nie pracuję nie mam nadziei na pracę. Kilka dni temu byłem badany przez komisję lekarską w związku z moją prośbą o warunkowe zwolnienie z więzienia. Co da przegląd lekarski nie wiem, wiem tylko że z sercem moim coraz gorzej i czuję się bardzo kiepsko.

Żeniu droga, obiecujesz w ostatnim liście przyjazd w sierpniu do Barczewa, proszę na wszystko nie przyjeżdżać, droga daleka na Twoje zdrowie, poza tym od stacji kolejowej do więzienia jest około $3 \mathrm{~km}$. Dziękuję za Twoje dobre serce, ale stanowczo proszę nie przyjeżdżać, tym bardziej że mam nadzieję zwolnienia i zobaczenia Cię w niedługim czasie. Ogromnie ucieszyłem się wiadomością że od września uczyć będziesz, że jesteś zdrowa, po prostu spadł mi kamień z serca. I największe zmartwienie odpadło.

Kochana Żeniu! List mogę pisać tylko raz w miesiącu, następnego spodziewaj się dopiero w miesiącu wrześniu. Całuję rączki mamusi i Tobie. Wszystkie moje myśli są u Was w domu.

Franek. 
Łabowa 29. 1. $1956 \mathrm{r}$.

Jestem w Łabowej, 16 km od Nowego Sącza, w połowie drogi do Krynicy. Pracuję jako zwykły robotnik $\mathrm{w}$ garbarni, raczej w małej garbarence. Jest tutaj 16tu pracowników: kierownik, majster, 2 chorych, 2 stróżów i 10 w produkcji razem ze mną.

Zaszło tu jakieś nieporozumienie, albo złośliwość ludzi którzy dali mi tę pracę. Powiedziano mi, że praca bardzo lekka i łatwa, mierzenie powierzchni wyprawionej skóry. Zarobek od 1200-1400 zł. Tymczasem jest zupełnie inaczej, trzeba wykonać trzy czynności:

1) obcinać skórę, by nie było na brzegach strzępów i zgrubień. Obcinanie skóry dla mnie bardzo trudne, trzeba wprawy i ostrego noża, którego pracownik sam musi sobie sprawić. Jest nóż, który odziedziczyłem w spadku, ale tak tępy, że trzeba ostrzyć na osełce co 15 minut, a ostrzyć też trzeba umieć.

2) odmierzyć za pomocą przyrządu powierzchnię [...]

3) pakowanie - tutaj wielka trudność dla mnie. Trzeba 20 skór poskładać, wszystkie ostrym narzędziem przebić, przeciągnąć ręcznie, związać, przybić plombę, pieczęć i załączyć karteczkę ile jest metrów. Ja gwoździa do ściany wbić nie potrafię, by młotkiem nie uderzyć się w rękę, a tutaj trzeba kilka razy uderzyć sporym młotkiem, by przebić te 20 skór.

Robotnik wykwalifikowany, który tę pracę wykonywał kilka lat, zarabia 900-1000 zł. miesięcznie. Ja zaś od 23 do 28 bm zarobiłem 50 złotych, lewą rękę mam poranioną i obandażowaną, prawą pod wieczór ruszyć nie mogę. Zarobiłem 50 złotych, a pracowałem od 7-mej rano do 19-20 wieczór, przy kopcącej lampie naftowej. Po pracy prawej ręki nie czuję. Wczoraj byłem tak zmęczony, że zataczałem się i do łóżka dojść nie mogłem. A warunki pracy jeszcze gorsze, obiecano mi pokój, którego nie ma. Musiałem szukać mieszkania, znalazłem małą izdebkę za którą płacę 50 zł. miesięcznie. Izba nie opalana (brak pieca), zimno, okno wychodzi na podwórze, pod oknem gnojnik i chlew (mieszkała tam nauczycielka, obecnie wybudowano szkołę, w której się ulokowała).

Wieś w połowie spalona, jest mały drewniany kościółek, poczta, filia spółdzielni gromadzkiej i piekarni, z której są wszyscy zadowoleni, bo jest co jeść. W spółdzielni można dostać cukru, kawy i chleba. Na wsi nic kupić nie można, ani jajek ani mleka. Przez cztery dni nic w ustach nie miałem. Wczoraj dopiero kupiłem sobie bochenek chleba, cukier i kawę. Pożyczono mi garnek i garnuszek. Gotuję sobie teraz kawę u stróża na piecyku, mam chleb i jestem zadowolony, że mam co jeść. Ale rozpacz mnie ogarnia, co będzie dalej. Czy dam radę i jaki będzie mój zarobek. Ale to nic, jakoś to będzie, jestem twardy w końcu musi być dobrze, do Wisły (?) nie pójdę.

Piszę dopiero dzisiaj, w niedzielę (w izbie gdzie pracują, między skórami, gdzie również zimno jak w psiarni) bo w zwykły dzień, po pracy byłem tak zmęczony, że ręką ruszyć nie mogłem. Dziś jeszcze spróbuję napisać kilka słów, znajomych alarmować, by szukali dalej pracy. Na robotnika się nie na daję, z powodu serca, które gwałtownie daje znać o sobie. Chwilami przy obcinaniu skór nic nie widzę i muszę mocno oprzeć się o stól, by nie upaść, tak wszystko w oczach mi się kręci. I trwa to dość długo. Nie wiem za co los mści się na mnie i jest tak bardzo niełaskaw.

Podczas jednej z wizyt u Franciszka Studzińskiego w więzieniu w Iławie Eugenia Starościn doznała szoku. Franciszek został bestialsko skatowany ${ }^{50}$.

${ }^{50}$ Franciszek Studziński w wyniku pobicia w więzieniu w Iławie „przestał być mężczyzną". Informacja rodzinna. 
W drodze powrotnej do Bytomia zrozpaczona dostała ataku szału. Pogotowie wyprowadziło ją z pociągu i skierowało na leczenie do zakładu psychiatrycznego. Zapadła na schizofrenię spowodowaną traumatycznymi doświadczeniami - wojną, prześladowaniem aparatu bezpieczeństwa oraz wielomiesięcznym więzieniem. Eugenii nieustannie wydawało jej się, że jest śledzona. Wybuchała gniewem. Zdarzało się to nawet podczas mszy w kościele ${ }^{51}$. Nie inaczej było na pogrzebie Franciszka Studzińskiego, który odszedł 23 maja 1964 r. Była przekonana, że ceremonię na bytomskim cmentarzu obserwują z ukrycia funkcjonariusze Służby Bezpieczeństwa. Przerażona krzyczała: „Oni tam są!” Po śmierci matki w roku $1974^{52}$ wysyłana była wielokrotnie na leczenie do Lublińca, gdyż odmawiała przyjmowania pokarmów. Ostatnie lata życia spędziła w Zakładzie Opiekuńczo-Leczniczym w Bytomiu przy ul. Piekarskiej, gdzie zmarła 29 kwietnia 1985 r. Została pochowana w jednym grobie ze swoją matką, niedaleko miejsca zamieszkania, tj. na Cmentarzu Parafii Świętej Trójcy w Bytomiu. Franciszek Studziński spoczywa na Cmentarzu Mater Dolorosa, po drugiej stronie ulicy...

23 maja 2013 r. Sąd Okręgowy w Zielonej Górze ${ }^{53}$, „po rozpoznaniu sprawy z wniosku Ministra Sprawiedliwości w przedmiocie stwierdzenia nieważności wyroku Wojskowego Sądu Rejonowego w Zielonej Górze [...] skazującego Eugenię Starościn za czyn z art. $86 \S 2$ KKWP na podstawie art. 1 ust., art. 2 ust. 1 i 2 ustawy z dnia 23 lutego 1991 r. o »uznaniu za nieważne orzeczeń wydanych wobec osób represjonowanych za działalność na rzecz niepodległego bytu Państwa Polskiego « [...] postanowił stwierdzić nieważność wyroku [...] i orzec, że koszty postępowania ponosi Skarb Państwa". Sąd orzekł, że "zgromadzony materiał dowodowy w pełni pozwala na uznanie, iż czyn przypisany Eugenii [...] stanowił w sposób oczywisty wyraz jej działalności na rzecz niepodległego bytu Państwa Polskiego, zaś wydany w tej sprawie wyrok - mimo, iż orzeczona nim kara więzienia została Eugenii Starościn darowana - stanowił represję wobec Eugenii Starościn za jej uprzednią działalność niepodległościową"54. „[...] O ile na podstawie przepisów amnestyjnych darowano Eugenii Starości orzeczoną karę więzienia, to wskazanym wyrokiem zastosowano również wobec niej sankcję polegającą na pozbawieniu jej praw publicznych, która to sankcja była wobec niej wykonywana, zaś - jak wynika z akt sprawy, w tym w szczególności kierowanych przez E. Starościn już po uprawomocnieniu pism, $\mathrm{w}$ tym wniosku o ułaskawienie - represja

\footnotetext{
${ }^{51}$ Informacje rodzinne.

52 Prawnym opiekunem Eugenii Starościn po śmierci jej matki, był dziadek autorki - Józef Kułagowski (ur. 29 kwietnia 1935 r. w Kuczkach, zm. 20 grudnia 2005 r. w Katowicach).

${ }^{53}$ Instytut Pamięci Narodowej, Oddział w Poznaniu. Kopia postanowienia Sądu Okręgowego w Zielonej Górze (sygn. akt II Ko 117/12) została dołączona do akt sprawy Sr 156/53 w Instytucie Pamięci Narodowej pod sygnaturą IPN Po 2/2254/2, s. 266.

${ }^{54}$ Tamże, s. 276.
} 


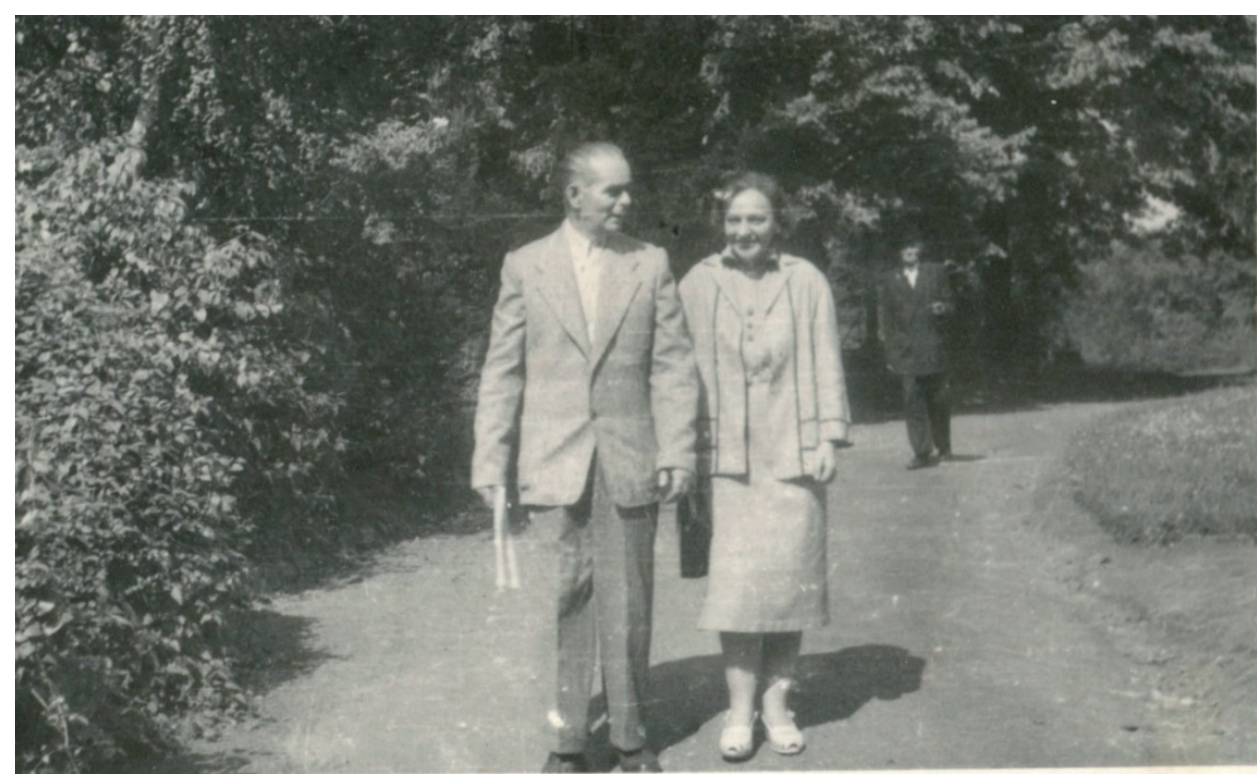

Jedyne zachowane wspólne zdjęcie Eugenii Starościn i Franciszka Studzińskiego.

Fotografię wykonano między 1955 r. a 1964 r. Miejsce nieznane. Zbiory prywatne autorki.

ta dla niej była szczególnie dotkliwie odczuwalna, bowiem uniemożliwiała jej czasowo powrót do wykonywania zawodu nauczyciela, który uważała za swoje powołanie i którego wykonywanie dawało jej ogromną satysfakcję $[\ldots]]^{\prime 55}$. Skonstatowano, że „na wyznaczone w celu rozpoznania wniosku posiedzenie Sądu za wnioskodawcę nie stawił się nikt. Nie stawił się również nikt za nieżyjącą Eugenię Starościn, albowiem Sąd ustalił w toku czynności przygotowujących posiedzenie, iż Eugenia Starościn zmarła nie pozostawiając osób najbliższych". Szkoda, iż sąd ograniczył się jedynie do poszukiwań potomków Żeni. Najbliższa krewna - Teresa Kułagowska-Szymańska, córka Kamili z domu Mazacz (siostry jej matki), oraz jej zstępni nic o procesie rehabilitacyjnym nie wiedzieli. Informację o procesie rehabilitacyjnym odnaleźli w Internecie rok po ogłoszeniu wyroku.

Niewypowiedzianym smutkiem napawa fakt, że ludzie, którzy Eugenii Starościn, Franciszkowi Studzińskiemu i wielu innymi członkom organizacji WiN zniszczyli życie, uniknęli odpowiedzialności za swoje czyny.

55 Tamże, s. 278. 
Katarzyna Kułagowska Silva

\title{
Żeniu! Dziecino droga! Historia znajomości łączniczki AK i jej dowódcy Franciszka Studzińskiego
}

\begin{abstract}
Streszczenie
Tekst opowiada historię komendanta Okręgu AK terenu tarnopolskiego pułkownika Armii Krajowej Franciszka Studzińskiego i jego łączniczki oraz osobistej sekretarki Eugenii Starościn, działaczki AK oraz - w okresie późniejszym - organizacji Wolność i Niezawisłość. W artykule omówiono aktywność konspiracyjną obu postaci w okresie II wojny światowej oraz ich powojenne losy naznaczone przesłuchaniami, więzieniem, licznymi przeprowadzkami i problemami ze znalezieniem pracy.
\end{abstract}

Słowa kluczowe: Starościn Eugenia, Studziński Franciszek, Żeglin Bronisław, Armia Krajowa, Wolność i Niezawisłość, żołnierze wyklęci, żołnierze niezłomni, działalność konspiracyjna

\section{Zhenya! My love! The story of the relationship between a Home Army military courier and her commander, Franciszek Studziński}

\begin{abstract}
The article presents the story of the Home Army colonel in the district of Tarnopol, Franciszek Studziński, and his courier and personal assistant Eugenia (Zhenya) Starościn, an activist of the Home Army and in subsequent years of the Freedom and Independence organization. The article presents their conspiracy activity during the Second World War and their post-war experiences: interrogations, imprisonment, numerous relocations, and problems with finding employment.
\end{abstract}

Keywords: Starościn Eugenia, Studziński Franciszek, Żeglin Bronisław, Home Army, Freedom and Independence, damned soldiers, cursed soldiers, conspiracy 